\title{
Baptizing the Romans
}

\begin{abstract}
This article focuses on Ordo Romanus XI, a liturgical script that describes the process for performing baptism, including its preparatory meetings. First, the essay discusses the context in which the source was created, and second draws on its evidence to understand elements of the society of its origin. It is argued that the source was composed in the city of Rome in the second half of the seventh century, and it was intended to introduce innovations into the celebration and conception of baptism there. While previous research has characterized the source as one milestone in the history of baptism, a close reading of it provides valuable hints as to the behavior, attitudes, and identity of seventh-century Romans, both on individual and collective levels. Baptism inducted people into Christian society, cleansed them from sin, and made salvation possible. It mediated both human and supernatural relationships. Further, it strengthened Christian belief, gender roles, and the conception that Romans were the new Israelites.
\end{abstract}

\section{Introduction}

The administration of baptism may seem a prosaic or unremarkable affair in Christian Europe, but this liturgy featured prominently in one dramatic early-medieval narrative. In the course of his History of the Lombards, Paul the Deacon recounted the disruption of the rite during the otherwise model reign of Grimoald I (r. 662-71). ${ }^{1}$ Frustrated by the aid the city of Forlì had given to his Byzantine adversary Constans II (r. 641-68), Grimoald "unexpectedly fell upon that city on that most holy Easter Vigil, at the hour when baptism was being celebrated, and carried out such a great massacre of men that he killed even those deacons who were baptizing the little infants". ${ }^{2}$ After telling of this carnage Paul immediately remarked that the destruction of Forlì was so thorough that the city remained largely uninhabited when he wrote in the mid-eighth century. Unstated, but strongly implied by Paul's words, was an intimate connection between the health of the city and baptism. A massacre at this pivotal moment in the liturgy symbolically robbed the city of its future.

It would be impossible to investigate further the nature of the baptismal ceremony cut short by Grimoald's assault, owing to the lack of any sources that describe it. It may well be that it had been influenced by papal norms of worship, but like so much of early-medieval liturgy, its form remains a mystery. Historians are more fortunate when they turn their atten-

\footnotetext{
${ }^{1}$ For his reign, Goffart 1988, 403-412.

${ }^{2}$ Bethmann and Waitz (eds.) $1878,196$. My translation.
} 
tion to baptism in the same period further south, in the city of Rome. Baptism in the Eternal City may not have been the setting for so violent a confrontation, but its significance for the society of early-medieval Rome was no less profound. The source to which I will turn most of my attention is known as Ordo Romanus XI (henceforth OR XI). ${ }^{3}$ First I intend to describe the source and its unusually complicated story, which must be understood before delving into its evidence; and second, I wish to investigate what it suggests about the broader society of Rome when it was written. Bernard Botte once argued that a close reading of baptismal texts has much to tell students of the liturgy about how to understand liturgical sources more generally, ${ }^{4}$ but the same texts can equally inform historians about practices and mentalities in the societies that observed baptism.

\section{Reading the Source: Ordo Romanus XI}

OR XI is an ordo or liturgical script, a text that communicates the actions of a liturgy. Like other ordines, the genre has largely been studied by scholars of the liturgy to reconstruct the form of early-medieval worship, although it has been neglected even by experts of medieval Rome. ${ }^{5}$ As a step-by-step flowchart of what must occur leading up to and during a Roman baptism, OR XI is laconic, unyielding, and focused on the arrangement of worship. Its flavor is captured well, for instance, in these pivotal chapters: "Then the pope baptizes one or two of the infants, or as many as he wishes, and the rest are baptized by the deacon whom he commands. Taking the infants in their hands, they offer them to one priest. The priest makes the sign of the cross with chrism on the crown of their heads with his thumb, saying: "Almighty God, the Father of our Lord Jesus Christ, and the rest". ${ }^{6}$ In spite of its terse style and narrowly focused substance, the source inadvertently can tell modern investigators so much about cultural assumptions when it was first written. In some ways OR XI is typical of ordines, but it is unusual in its intensive engagement with the laity. Most ordines tend to exclude the laity in favor of a singular focus on the clergy, but since OR XI is a baptismal text, they were naturally incorporated as they are the main recipients of the ceremony.

OR XI derives from the city of Rome, and it has been dated imprecisely to some point between the end of the sixth century and the seventh century. ${ }^{7}$ Although the text was likely to have been penned within this broad range, I would further restrict its dating to the second half of the seventh century. The main reason to identify this period for its composition is that it operated under the assumption that there was a significant population of Greek speakers in Rome, a number that would have been swollen by the presence of refugees from the Muslim

\footnotetext{
${ }^{3}$ Andrieu (ed.) 1931-61, vol. 2, 363-413 (his introduction to the source); and 415-447 (his edition). After the pages from Andrieu's edition, I provide specific chapters of his ordines in parentheses. These are indicated by a colon (e.g., chapter 1 of OR XI is OR XI:1). A Spanish translation can be found in Urdeix (ed.) and Lligadas 1995; and an English translation in Whitaker and Johnson 2003, 244-251.

${ }^{4}$ Botte 1952 .

${ }^{5}$ The standard edition for early-medieval ordines is Andrieu (ed.) 1931-61, although there remain some examples that Andrieu did not incorporate in these volumes. For a discussion of the genre of texts, see Martimort 1991. For source criticism of ordines, Nelson 1975; and Pfaff 1992.

${ }^{6}$ Andrieu (ed.) 1931-61, vol. 2, 445-446 (OR XI:96-97). The translation is from Whitaker and Johnson 2003, 251 (with modification).

${ }^{7}$ Andrieu (ed.) 1931-61, vol. 2, 413; Chavasse 1958, 163-164.
} 
conquests. $^{8}$ It is likely that the popes in the late-seventh and early-eighth century who spoke Greek as their mother tongue would have been particularly sensitive to the linguistic needs of this population. ${ }^{9}$ OR XI offers the option for the creed to be chanted either in Greek or Latin and chanting in Greek was given as the first option, implying that it had priority over Latin. ${ }^{10}$ One subtle sign of the presence of either Greek-speaking popes or populace is the form of the creed. Rather than the Apostles' Creed, which had traditionally been more popular in Rome, it features the Creed of Nicaea-Constantinople, which had circulated more widely in the Greek-speaking East. ${ }^{11}$ This form of creed was already known in Rome from the mid-sixth century, as attested by an encyclical letter of Pope Vigilius I (537-55), ${ }^{12}$ but OR XI preserves its first liturgical use. This particular creed may have been incorporated into the baptismal ceremony for Greek-speaking newcomers, due to the familiarity the Greek-speaking popes had with it, because it responded to the theological controversies of the day, or some combination of these explanations.

I would argue that the text cannot be younger than the reign of Pope Boniface V (619-25), because his papal biography attributes to him a decree by which deacons would be aided at the Easter Vigil by attendant (sequens) subdeacons rather than by acolytes. ${ }^{13}$ OR XI seems to reflect the exclusion of acolytes from assistance at the baptism during the Easter Vigil, although they had previously appeared during the pre-baptismal meetings known as scrutinies. ${ }^{14}$ The problem with this reading of OR XI is that, at least in its current form, attendant subdeacons similarly do not appear in the course of the chapters that handle the baptism. It is possible that these clergymen were omitted by readers north of the Alps, who were mystified by the obscure attendant subdeacon. The original presence of the attendant subdeacons in the text would explain who was responsible for carrying the thurible with the incense and relaying the children from the deacons to the pope, for no one else was assigned the tasks; at least for the former, the attendant subdeacon had a similar duty in the near-contemporary papal Mass. ${ }^{15}$ Because they too are imprecisely dated, I would hesitate to base the chronology on certain formularies from the Gelasian Sacramentary or the Roman antiphoner. ${ }^{16}$ If it is indeed from the late-seventh century, this would make OR XI one of the two oldest ordines, if not the oldest. Because of the incomplete state of previous evidence for the liturgy, this is one of the first liturgies that we can reconstruct in detail.

\footnotetext{
${ }^{8}$ Sansterre 1993. For his discussion of the use of the Greek creed in the city of Rome, see vol. 1, 220-225.

${ }^{9}$ Richards 1979, 270.

${ }^{10}$ Andrieu (ed.) 1931-61, vol. 2, 434-435 (OR XI:62-66); Mohlberg (ed.) 1981, 48-51 (Lib. I, formula XXXV, nos. 310314).

${ }^{11}$ Kelly $1972,344-348$.

${ }^{12}$ Mansi (ed.) 1759-1798, vol. 11, coll. 50-51 (esp. 50-51); PL 69:53-59 (esp. 56-57).

${ }^{13}$ Mommsen (ed.) 1898, 168: "Hic constituit ut in Lateranis acolothus non baptizet cum diacono, sed subdiaconi sequentes."

${ }^{14}$ Andrieu (ed.) 1931-61, vol. 2, 418, 420, 422-423, 427, 434, 434-435 (OR XI:2, 10, 13, 18, 21, 41, 62, 64), cf. Andrieu (ed.) 1931-61, vol. 2, 443-447 (OR XI:83-105).

${ }^{15}$ For these unassigned duties in OR XI, see Andrieu (ed.) 1931-61, vol. 2, 444, 446 (OR XI:90, 99). For the attendant subdeacon carrying the thurible in the papal Mass, see Andrieu (ed.) 1931-61, vol. 2, 80, 82, 87-88 (OR I:41,46, 59).

${ }^{16}$ McKinnon 2000 puts the creation of the antiphoner in the late-seventh century, which would reinforce my dating. However, this argument is not accepted by all scholars. For the chronology of the Gelasian Sacramentary, see Chavasse 1958 and Moreton 1976. Even if the writing of the manuscript as a whole was in the eighth century, it would not provide a date for its individual formularies, some of which may be far older.
} 
The editor responsible for producing the modern edition of OR XI, along with forty-nine other ordines, was Michel Andrieu. ${ }^{17}$ Andrieu created the edition from fifteen manuscripts. Seven of these came from what he dubbed Collection A, which contains texts that he identified as having come from Rome, even though the manuscripts themselves were compiled by anonymous (though likely clerical) scribes in Francia between 700 and 750. The manuscripts he classified in this collection provide a version of OR XI closer to the original text. Seven of the manuscripts were from Collection B, compiled by anonymous scribes in the second half of the eighth century, which Andrieu argued were more fully "Gallicanized," or modified according to the preferences of Frankish readers. When it comes to OR XI, the primary differences between the two collections is that Collection B included only 89 of OR XI's original 105 chapters, and it further provided complete texts of catechetical material abbreviated in Collection A. One other witness to OR XI (MS. Wolfenbüttel, Landesbibliothek 1475) also survives independently of either collection, which has proved useful to confirm readings from Collection A.

In reading through OR XI, it is difficult to escape its 'low' level of Latinity in comparison with classical norms. ${ }^{18}$ In instances in which we would anticipate ablatives, accusatives are found instead. Unlike scribes in Francia who had learned an artificially transmitted form of Latin, in the city of Rome Latin was still a living and evolving language, with its case endings in flux. ${ }^{19}$ Some of the variants Andrieu recorded in the footnotes to his edition reveal that the endings of OR XI were emended according to the norms of classical Latin, which in some cases meant introducing correct forms for the first time. ${ }^{20}$ While Carolingian scholars greatly desired Roman liturgical books, they did not hesitate to improve the orthography, syntax, and grammar of these sources. ${ }^{21}$ A close analysis of certain characteristics of the text suggests that it may have been subjected to further editorial touches by Frankish scribes that extend beyond linguistic changes, ${ }^{22}$ but at its core, OR XI is generally held to represent an authentic Roman liturgy that was exported because of the Carolingians' idealization of Roman worship.

Only one competing theory would push the date of the composition of the original text of OR XI into the eighth century, locate its inception in Francia, and argue that it reflected liturgical practice there. The scholar who originally argued this was Thierry Maertens, although it was carried on by his student M. M. van Molle. ${ }^{23}$ This line of thought was cited by Joseph Lynch who, though noncommittal about whether he accepted it in full, gave an accounting of this criticism and added reasons to bolster Maertens' rationale. ${ }^{24}$ Nearly all of the evidence

\footnotetext{
${ }^{17}$ For the manuscripts of OR XI, see Andrieu (ed.) 1931-61, vol. 2, 363-369; Palazzo and Beaumont 1998, 182-185; Vogel, Storey, and Rasmussen 1986, 144-155. For more on the manuscripts of ordines and what their construction demonstrates about religious mentalities in the Carolingian realm, see the contribution by Arthur Westwell in this volume.

${ }^{18}$ Andrieu (ed.) 1931-61, vol. 2, 378-379.

${ }^{19}$ Löfstedt 1959, 3-9.

${ }^{20}$ To give the example from OR XI:44, the scribe of Collection B corrected the cum quattuor libros of the original text to cum quattuor libris and cum turabula et incensum to cum turibulis et incenso (thus also correcting the internal spelling of turabula).

${ }^{21}$ Bullough 1977.

${ }^{22}$ In addition to attendant subdeacons, note the switching off between the terms presbyter and sacerdos in the document, which may indicate later editing (however inconsistent): Neunheuser 1983, 109, n. 56.

${ }^{23}$ Maertens 1962, 204, 207-10, 256; Van Molle 1964.

${ }^{24}$ Lynch 1986, 170-171, 290.
} 
proposed for identifying this date or place fall apart upon closer examination. While it is true that no manuscripts of OR XI can be dated before the early-ninth century, this only proves that OR XI must antedate this time period. ${ }^{25}$ The date of the manuscripts does not determine anything more substantial about the date of the source; this argument confuses the dating of manuscripts and the texts within them. The Latin term for godfather, patrinus (or a variant of this spelling), was not a novelty of OR XI, but unambiguously appeared by the mid-seventh century in the Chronicle of Fredegar. ${ }^{26}$ Although this was not used in the context of the baptismal rite, the meaning of it was applied to a similar relationship and it can be translated as such. Although Lynch insisted that Christine Mohrmann offered linguistic evidence of the late dating and Frankish origin of OR XI, he provided no reference to Mohrmann's writings. ${ }^{27}$ To my knowledge, Mohrmann never published an extended discussion of OR XI. In the one comment I have been able to locate on her work about OR XI, Mohrmann did not disagree with Andrieu's dating, but rather analyzed the interesting usage of the term praefatio in OR XI. ${ }^{28}$ None of these authors furnished any explanation as to why a supposed Frankish author would have arranged a liturgy with a Greek creed or written with obvious Latin errors in spite of the attention given to classical norms in the language of the Carolingian age.

Even as scholars debated aspects of its original composition, the significance of OR XI has never been denied. The primary focus on the text, obvious by its contents, has been on the history of baptism. ${ }^{29}$ This source represents the first unambiguous evidence of infant baptism since the recipients of baptism were carried around and some of them had not yet been weaned. ${ }^{30}$ By the seventh century, the definitive transition between adult and child baptism was complete in the city of Rome. The practice of baptizing infants had long been accepted in the Church; the turning point is often seen as the theoretical justification provided by Augustine (354-430), who argued that this pre-existing practice served to wash away Original Sin. ${ }^{31}$ OR XI was also used by Joseph Lynch as part of his work on godparents. ${ }^{32}$ Susan A. Keefe traced the reception of OR XI in the Carolingian realm, demonstrating that even while purporting to perform the Roman liturgy, Franks often drew from it in variable ways rather than adopting it wholesale. ${ }^{33}$ Carolingian texts would, for instance, eliminate scrutinies or postpone confirmation and yet regard the new texts they produced as following Roman tradition. Though OR XI may not have been followed literally, many of its components would become mainstays within the Roman Catholic tradition of baptism. ${ }^{34}$ The problem with past scholarship is that OR XI appeared as one milestone in a long survey on baptism without focusing on the source and its peculiarities.

\footnotetext{
${ }^{25}$ Buchinger 2016, 160-161.

${ }^{26}$ Krusch (ed.) 1888, 82. For translations of the term, Dutton 2004, 18; Hen 1995, 140.

${ }^{27}$ Lynch 1986, 171.

${ }^{28}$ Mohrmann 1958, 302-303.

${ }^{29}$ E.g., Fisher 1965, 1-33, but see the other examples that are recurrent in the notes.

${ }^{30}$ Carried around: Andrieu (ed.) 1931-61, vol. 2, 434, 446 (OR XI:62, 97, 98); Breastfed: Andrieu (ed.) 1931-61, vol. 2, 446 (OR XI:103). For discussion, Chavasse 1958, 164-165; Fisher 1965, 3; Neunheuser 1983, 89-90, $106-107$.

${ }^{31}$ Didier 1956; Wright 2007.

${ }^{32}$ Lynch 1986, 31-34.

${ }^{33}$ Keefe 2002, vol. 1, 46-60.

${ }^{34}$ Fisher 1965, 3, 21; Kelly 1985, 202, 227-229, 254; Neunheuser 1983, 89-90. For one concrete example, see the literal borrowing from OR XI in Vogel and Elze (eds.) 1963-72, vol. 2, 24-40 (formula XCIX, nos. 85-158); vol. 2, 93-112 (formula XCIX, nos. 337-397), although the nature of this source has recently come under renewed discussion.
} 
The occasion for the composition of OR XI has never been satisfactorily addressed. Like ordines in general, this baptismal script reflected a desire to organize a complicated public service: for instance, to clarify the responsibilities of the members of the clergy associated with baptism. Worship was important in preserving the society as a whole. With this being said, however, I suspect that there must have been some special impetus to write down OR XI beyond these justifications for any ordo. After all, only a small fraction of liturgies performed were ever committed to parchment, and so when we find written evidence of a liturgy, it is useful to inquire why it exists. In saying this, I doubt that the purpose of this ordo was for Carolingian use since there is no evidence that the Roman clergy regularly supplied the Frankish clergy with texts, although this is where it was carried by Carolingian pilgrims on their own impetus and it generated considerable interest and commentary. I am skeptical of the possibility that this source was merely intended to preserve instructions of how to baptize infants for the Roman population either. This ordo assumes that the reader already knew how to perform a baptism, which is likely why it is strangely abbreviated at the most critical moment. ${ }^{35}$ From the ordo alone we would not know how many times the infant had to be immersed. It is only from a letter of Gregory I (590-604) that we learn that the number was three. $^{36}$

My hypothesis is that this baptismal ceremony reflects recent changes or a rethinking of aspects of baptism and that OR XI was intended either to memorialize or promote the novelties introduced. Although one might anticipate that the rite of baptism would become simpler when it switched to infant baptism, in fact, it appears to have become more elaborate. ${ }^{37}$ The most striking new feature is that, at some point, the number of preparatory gatherings for baptism known as scrutinies had ballooned from three (still attested in a letter of the Roman John the Deacon from ca. 500) to seven. ${ }^{38}$ Certain choices suggest that this change may have been recent. The scrutinies recycle and repeat texts to an unusual degree; this flies in the face of the supposed "soberness and sense" of the Roman liturgy, a facet of which was the avoidance of repetition. ${ }^{39}$ The first scrutiny borrowed the text of the gradual from the Wednesday after the Fourth Sunday of Lent. ${ }^{40}$ Because the text of the music was borrowed from an already established celebration, it demonstrates the relative, if not the absolute, date. ${ }^{41}$ More strikingly, the scrutinies cannibalize themselves: the second, fourth, and fifth scrutinies were all identical to the first one. ${ }^{42}$ It has been suggested that no one seriously anticipated that a child would be taken to all of the preparatory meetings, and instead that any one of them

\footnotetext{
${ }^{35}$ Andrieu (ed.) 1931-61, vol. 2, 446 (OR XI:96). For discussion, Fisher 1965, 14; Neunheuser 1983, 119. In OR XI, it is assumed that the child already had a name before baptism: Andrieu (ed.) 1931-61, vol. 2, 418, 420, 426-427 (OR XI:2, 10, 35, 41), and for discussion, Fisher 1965, 149-150. The first appearance in Rome of the familiar baptismal formula Baptizo te in nomine patris et filii et spiritus sancti comes in the Gregorian Sacramentary: Deshusses (ed.) 1971-82, 336 (formula 206, no. 982), although it may have been used earlier.

${ }^{36}$ Norberg (ed.) 1982, vol. 1, 47-49.

${ }^{37}$ Stenzel 1958, 225.

${ }^{38}$ Cf. Wilmart (ed.) 1933, 171 and Andrieu (ed.) 1931-61, vol. 2, 442 (OR XI:81). On this as an innovation, see Stenzel 1958, 230, n. 31. For a broader discussion of scrutinies, Chavasse 1960.

${ }^{39}$ The famous formulation by Bishop 1918, 1-19.

${ }^{40}$ Hesbert (ed.) 1935, 76-77.

${ }^{41}$ For use of this method, McKinnon 2000, 137-144.

${ }^{42}$ Andrieu (ed.) 1931-61, vol. 2, 426, 441-442 (OR XI:38, 77, 79-80).
} 
would accomplish the requirements. ${ }^{43}$ If this was the case, however, OR XI made no provision for missing scrutinies. Seven would subsequently become the normative number of scrutinies in Rome and those influenced by it. ${ }^{44}$

It is unusual enough to find multiplication of scrutinies beyond what is strictly necessary, but what is more unusual is that the text provides a rationale for having selected seven of them. If OR XI is taken at its word, the increase was not motivated by a desire for more attacks against demons. ${ }^{45}$ Rather the author chose seven because it corresponded with the seven gifts of the Holy Spirit. ${ }^{46}$ These gifts were known in Rome, having been cited explicitly by Gregory I, and also by his contemporary, Isidore of Seville (d. 636). ${ }^{47}$ One of them, timor Domini ("fear of the Lord"), was mentioned in an antiphon chanted in the course of the third scrutiny. ${ }^{48}$ There seems to be nothing controversial about the gifts of the Holy Spirit or associating them with baptism. One of the prayers in the Gelasian Sacramentary states that the seven gifts of the Holy Spirit were received through baptism. ${ }^{49}$ What is anomalous is that they are utilized as an organizational principle for a set of liturgies, a scheme one scholar characterized as "entirely artificial". ${ }^{50}$ It was foreign to ordines to provide any theoretical underpinning or symbolism behind individual aspects of the liturgy. ${ }^{51}$ For instance, it has been argued that seven candelabra were used for the papal Mass because of the seven candelabra found in the Book of Revelation, but the text itself does nothing to clarify the issue. ${ }^{52}$ One of the few reasons ostensibly provided for liturgical action in the near-contemporary Mass ordo is more likely an interpolation than a feature of the original text. ${ }^{53}$

Two other features of OR XI compound the likelihood that it was envisioned as a refashioning of baptism. Toward the end of the text, there is a stern reminder that confirmation must be part of baptism, ${ }^{54}$ making it possible that this had been a bone of contention, albeit one that finds no echo in contemporary texts. It is also plausible that this ceremony of baptism was intended to eliminate rites that previously had been incorporated in it, including the blowing on candidates as part of the exorcism known as exsufflatio (even as it retained other means to attack the Devil) and the unction of a candidate's chest and shoulders. ${ }^{55}$ Such omissions have been explained in the past as unintentional and unreflective of how baptism was

\footnotetext{
${ }^{43}$ Fisher 1965, 9.

${ }^{44}$ Neunheuser 1983, 107. See for example Hanssens (ed.) 1948, 240.

${ }^{45}$ Kelly 1985, 210.

${ }^{46}$ Andrieu (ed.) 1931-61, vol. 2, 442 (OR XI:81).

${ }^{47}$ These seven, derived from Isaiah 11: 1-2, are listed explicitly in Adriaen (ed.) 1971, 320; Lindsay (ed.) 1911, vol. 1, 99-100: Sapientia, intellectus, consilium, fortitudo, scientia, pietas, and timor Domini. For a broader discussion of their role in Gregory I's writings, Dudden 1905, vol. 2, 352-357.

${ }^{48}$ Andrieu (ed.) 1931-61, vol. 2, 427 (OR XI:42): Venite filii audite me timorem Domini docebo vos.

${ }^{49}$ Mohlberg (ed.) 1981, 72 (Lib. I, formula XLIII, no. 443).

${ }^{50}$ Cramer 1993, 143.

${ }^{51}$ Romano 2014, 65-66.

${ }^{52}$ Seven candelabra in Andrieu (ed.) 1931-61, vol. 2, 82-83, 107 (OR I:46,49, 125), as derived from Revelation 1:12-13, 20; 2:1,5. This was argued by Battifol 1919, 76 .

${ }^{53}$ I.e. that a piece of bread remained on the altar because the altar should not be without sacrifice. Andrieu (ed.) 1931-61, vol. 2, 101 (OR I:105).

${ }^{54}$ Andrieu (ed.) 1931-61, vol. 2, 446 (OR XI:102). This is the first use of the verb confirmare in which it is indisputable that the meaning is "to confer confirmation." Fisher 1965, 163; Neunheuser 1983, 200-201.

${ }^{55}$ Wilmart (ed.) 1933, 172, 174. For exsufflatio, see Kelly 1985, 228; and for its prehistory, Van Slyke 2004.
} 
administered, ${ }^{56}$ but they may well have been intentionally suppressed in the performance of baptism.

Some methodological considerations are in order before we exploit the content in OR XI. As with previous scholarly examination of the source, here I read it in the context of other Roman liturgical sources that spell out its abbreviated incipits: prayer formularies from the Gelasian Sacramentary, antiphons from the Roman antiphoner, and Roman pericopes. In all cases, it cannot be confirmed that the extant versions of these texts would have been identical with those circulating in Rome when OR XI was composed, but even if some later modifications were made, their flavor was sufficiently similar. Of these three other sources that inform the text, the relationship between OR XI and the formularies from the Gelasian Sacramentary that address baptism deserves particular attention. ${ }^{57}$ The connection between these sources has been a controversial issue with no clear resolution. ${ }^{58}$ It has been widely assumed that one of them was the source for the other with no clear determination as to which direction the influence ran. ${ }^{59}$ Although the matter requires further study, as a working hypothesis I find it more probable that these texts were created in the same Roman milieu and perhaps drew from similar libelli (short pamphlets containing liturgical texts) that contained baptismal prayers. ${ }^{60}$ The genre of texts to which OR XI belongs ought also to be considered. Ordines tend to give an accurate idea of the liturgy they describe, but in most cases, one cannot prove that the worship was accomplished exactly as written. Contemporaries took baptism seriously, but most occurrences of it took place without incident and so were unremarked upon. Frustratingly few narrative sources touch on baptism, and those we have were noteworthy because they deviated so far from the norm. In addition to the opening anecdote, Byzantine sources speak of the baptism of the future emperor Constantine V (r. 741-75) in 718. ${ }^{61}$ As a baby, Constantine was said to have defecated in the baptismal font, leading him to be branded with the insulting nickname Kopronymos, i.e. "shit-named". The historicity of this account is suspect: It was either invented or at very least spread by his Iconophile opponents, who took this event as a prophecy of the evils that would befall the Orthodox Church during his reign.

A final methodological clarification is that my approach breaks with the dismissive attitude often taken toward the form of baptism preserved in OR XI. It has been criticized that babies were entirely passive and could not participate meaningfully in the process; ${ }^{62}$ that the

\footnotetext{
${ }^{56}$ Andrieu (ed.) 1931-61, vol. 2, 376-377.

${ }^{57}$ Mohlberg (ed.) 1981, 32-33 (Lib. I, formula XXVI, nos. 193-199); 36 (Lib. I, formula XXVII, nos. 225-228); 39 (Lib. I, formula XXVIII, nos. 254-257); 42 (Lib. I, XXVIIII, nos. 283-284); $42-43$ (Lib. I, formula XXX, nos. 285-287); 43 (Lib. I, formula XXXI, nos. 288-289); 44 (Lib. I, formula XXXII, no. 290); 44-46 (Lib. I, formula XXXIII, nos. 291 298); 46-48 (Lib. I, formula XXXIIII, nos. 299-309); 48-51 (Lib. I, formula XXXV, nos. 310-316); 51-53 (Lib. I, formula XXXVI, nos. 319-328); 67-68 (Lib. I, formula XLII, nos. 419-424); 70-72 (Lib. I, formula XLIII, nos. 431-443); 72-74 (Lib. I, formula XLIIII, nos. 444-452). Translation in Whitaker and Johnson 2003, 212-243.

${ }^{58}$ Stenzel 1958, 220-221.

${ }^{59}$ Chavasse 1958, 166-168, thought that OR XI was composed after the Gelasian formularies and was dependent on them. Andrieu (ed.) 1931-61, vol. 2, 404-405, argued that the Gelasian formularies were written first, and afterwards OR $\mathrm{XI}$, but then the Gelasian formularies were re-edited with reference to OR XI.

${ }^{60}$ Palazzo 1990.

${ }^{61}$ De Boor (ed.) 1883-85, vol. 1, 399-400; Mango and Scott 1997, 551-553; PG 95:337A-B.

${ }^{62}$ Fisher 1965, 9; Chavasse 1952, 30-31; Cramer 1993,143-144.
} 
ceremony was either ritualized or more bluntly: all exorcism and no catechism; ${ }^{63}$ and that it was a corruption of the ancient practice. ${ }^{64}$ The first two of these views say more about the expectations of worship of the often religious scholars who voiced them; these expectations included that active participation and understanding needed to be significant facets of baptism. The last criticism takes for granted, without any justification, that a unified process of Christian initiation existed in the ancient world and that we are well-informed about ancient baptism. ${ }^{65}$ It has been rare to attempt a sympathetic and impartial reading of the liturgy and what it said about those who were engaged in it, which is the approach that I adopt here. ${ }^{66}$

\section{Baptism and the broader society in Rome: individual level}

What I will demonstrate in the rest of this article is that a close reading of OR XI gives historians privileged hints as to changes in behavior, attitudes, and the identity of the recipients of baptism and other citizens of the city of Rome in the seventh century. This is a method I have employed in a book where I discuss the near-contemporary papal Mass, including the evidence from OR XI. ${ }^{67}$ But OR XI merits its own study; with its highly compressed formulation, it teems with information about seventh-century Rome. To discuss this data, it is best to break it down analytically, first into its significance for the individual and then for the society as a whole, though these two categories are artificial and in reality, they were interconnected. The individual was subsumed into society as a whole, something the ritual of OR XI made apparent.

The most significant effect that baptism had on the individual was the initiation into Christian society. Considering, at this point, there were likely only a small population of religious minorities in the Eternal City, Christian society was virtually coterminous with society as a whole. One prayer for instance requested that the elect (electi), i.e. those being baptized, would be numbered among the members of the Church. ${ }^{68}$ Not only would baptism be conferred, but all of what would later be referred to as the sacraments of initiation. During the course of the Easter Vigil ceremony, the newly baptized would be confirmed and consume his or her first Eucharist. ${ }^{69}$ For infants, the last of these would consist of the celebrant's daubing a taste of the consecrated wine on the infant's tongue. ${ }^{70}$ In Western Europe, confirmation and first Communion would over the course of centuries be decoupled from baptism and performed later, ${ }^{71}$ but in OR XI all three were still conceived of as part of a larger whole. The same requirements for fasting before the consumption of the Eucharist for adults applied equally to the infants. It was incumbent on them not to breastfeed before taking the Eucha-

\footnotetext{
${ }^{63}$ Chavasse 1952, 30-31; Chavasse 1958, 164-165; Cramer 1993, 143; Johnson 2007, 223; Keefe 2002, vol. 1, 111; Kretschmar 1970, 257; Lynch 1986, 291-292.

${ }^{64}$ Buchinger 2016, 163; Maertens 1962, 207.

${ }^{65}$ Bradshaw 2002, 144-170.

${ }^{66}$ But see Nocent 2000, 56-58, who sees OR XI as a courageous response to the decline in quality of Christian life.

${ }^{67}$ Romano 2014, 42, 97, 99, 200.

${ }^{68}$ Mohlberg (ed.) 1981, 39 (Lib. I, formula XXVIII, no. 254).

${ }^{69}$ Confirmation: Andrieu (ed.) 1931-61, vol. 2, 446 (OR XI:100-101); Eucharist: Andrieu (ed.) 1931-61, vol. 2, 446 (OR XI:103).

${ }^{70}$ Neunheuser 1972, 326-327.

${ }^{71}$ Fisher 1965, 101-108, 120-40.
} 
rist, ${ }^{72}$ although the result of this decision must have been a church filled with hungry, crying babies! Having a rite to initiate one into a society is a well-attested phenomenon, although Christian baptism differed considerably from other well-studied anthropological examples. ${ }^{73}$ Its occurrence was only tenuously tied to the biological cycle: It was scheduled after birth, but in OR XI the date was determined more directly by when the date of the Easter Vigil fell. It had nothing to do with sexual maturity, and there was no expectation that it would make anyone an adult. As I will shortly explain at greater length, the fear of damnation for those who remained unbaptized was too great to delay the liturgy until adolescence. Some similarities can be found with non-Christian rites of initiation, especially in the language we examine below of transformation, dying and being revived, or becoming a new man. A limitation was built in since an infant could not demonstrate on an individual level having become a new person; it was up to society as a whole to rear the child in such a way that he or she fulfilled this new status.

The ceremony not only incorporated the recipient into the Christian community, but the waters of baptism conferred physical and spiritual washing and the transformation of the person. The prayer texts called for cleansing, renewal, and regeneration; in one case, the regeneration of baptism was compared to the regeneration of humanity after the Biblical flood. ${ }^{74}$ The candidate would be reborn, ${ }^{75}$ and through baptism, the old man would become a new man. ${ }^{76}$ As one classic account put it, the recipients of baptism were spiritually dead throughout Lent, but in the course of the Easter Vigil liturgy, including the baptism, they were reborn. $^{77}$ This change was effected by the absolution from sin brought about by baptism. ${ }^{78}$ The human state lost through sin would also be restored: The collect in the first scrutiny asks "so that man's ancient dignity, which once, by sin, they had lost, by your grace may be restored in them". ${ }^{79}$ In the third scrutiny, the Gospel reminded listeners that Jesus had come to save people from sins,${ }^{80}$ a reference to the forgiveness from sins afforded by baptism. Although the baptismal texts do not spell out a well-articulated theology, they assume that the celebrants and the faithful were familiar with the concept of Original Sin and that only through Jesus could a believer be restored to humanity's prelapsarian state. ${ }^{81}$

As the concern with sin should indicate, baptism drew the recipient out of the mundane world and into the unseen, but potent, supernatural world. The figures that were most recurrent in this spiritual battleground were the Holy Spirit and the Devil. On the positive end of this equation, prayers asked for the benefit of the Holy Spirit and the granting of his power,

\footnotetext{
${ }^{72}$ Andrieu (ed.) 1931-61, vol. 2, 446 (OR XI:103).

${ }^{73}$ Eliade and Trask 1965. Specifically on Roman Catholic initiation, see Maldonado and Power 1979.

${ }^{74}$ Cleansing: Mohlberg (ed.) 1981, 39 (Lib. I, formula XXVIII, no. 255). Renewal: Mohlberg (ed.) 1981, 36 (Lib. I, formula XXVII, no. 225). Regeneration: Mohlberg (ed.) 1981, 36 (Lib. I, formula XXVII, no. 225); 39 (Lib. I, formula XXVIII, no. 256); 39 (Lib. I, formula XXVIII, no. 257); 47-48 (Lib. I, formula XXXIIII, no. 309 ); 67 (Lib. I, formula XLII, no. 419); 72-73 (Lib. I, formula XLIIII, no. 445), which includes the reference to the Biblical flood; 74 (Lib. I, formula XLIIII, no. 450).

${ }^{75}$ Mohlberg (ed.) 1981, 39 (Lib. I, formula XXVIII, no. 257); 47-48 (Lib. I, formula XXXIIII, no. 309).

${ }^{76}$ Mohlberg (ed.) 1981, 50 (Lib. I, formula XXXV, no. 316).

${ }^{77}$ Hardison 1965, 94-95, 153-156.

${ }^{78}$ Mohlberg (ed.) 1981, 67 (Lib. I, formula XLII, no. 419); 74 (Lib. I, formula XLIIII, no. 450).

${ }^{79}$ Mohlberg (ed.) 1981, 32 (Lib. I, formula XXVI, no. 193). The translation is from Whitaker and Johnson $2003,213$.

${ }^{80}$ Andrieu (ed.) 1931-61, vol. 2, 429 (OR XI:47-48). The Gospel reading is Matthew 1:1-21, esp. v. 21.

${ }^{81}$ Lukken 1973, 277-296.
} 
grace, or gifts. ${ }^{82}$ For instance, one prayer at the Easter Vigil referred to the Holy Spirit as the ultimate source for the cleansing communicated through baptism:

May the font be alive, the water regenerating, the wave purifying, so that all who shall be washed in this saving laver by the operation of the Holy Spirit within them may be brought to the mercy of perfect cleansing. ${ }^{83}$

Prayers further requested that an angel be sent, ${ }^{84}$ presumably as protection for the infant being baptized.

However, the rite placed greater emphasis on the dangers of the supernatural in asking for protection from the Devil and demonic forces. ${ }^{85}$ Ancient theologians argued for the indwelling of the Devil or demons, meaning that a person's body would literally serve as a host to them if one worshipped pagan gods, by practicing idolatry or eating their sacrifices, without baptism to counteract their presence. ${ }^{86}$ Even as this belief had come to appear archaic, the baptismal formulae and actions perpetuated this older strain of thought. The baptismal service contained exorcism prayers designed to cast out the Devil or demons, while others offered prolonged defense against the same forces. One lengthy prayer pronounced in the first scrutiny demonstrates well how an exorcism was performed at baptism and that its basis was the protective power of Jesus:

I exorcize you, unclean spirit, in the name of the Father and of the Son and of the Holy Spirit, that you may go away and depart from these servants of God. For he himself commands you, accursed one, damned one, he who walked with his feet on the sea and stretched out his right hand to Peter as he sank. ${ }^{87}$

Several of the prayers spoke not only about the Devil but his pompa, a term, transliterated from Greek into Latin, that over time lost its original meaning; it initially referred to the processions of idols carried out in ancient Roman games, or idolatry more generally, although gradually it came to refer by extension to luxury, vanities, and the sinful things of the world. ${ }^{88}$ It did not, as some have suggested, have anything to do with the Devil's demonic retinue. ${ }^{89}$ Special prayers were also devoted to expelling supernatural creatures (and presumably malevolent ones, since they are in need of ejection) from inanimate objects used in the ceremony, like water and salt. ${ }^{90}$ It was widely believed in the ancient world that demons lurked in the

\footnotetext{
${ }^{82}$ Andrieu (ed.) 1931-61, vol. 2, 445-446 (OR XI:93, 97); Mohlberg (ed.) 1981, 73 (Lib. I, formula XLIIII, no. 445 ); 74 (Lib. I, formula XLIIII, no. 451).

${ }^{83}$ Andrieu (ed.) 1931-61, vol. 2, 445 (OR XI:93); Mohlberg (ed.) 1981, 73 (Lib. I, formula XLIIII, no. 445). The translation is from Whitaker and Johnson 2003, 234.

${ }^{84}$ Mohlberg (ed.) 1981, 44-45 (Lib. I, formula XXXIII, no. 291).

${ }^{85}$ Kelly 1985, 201-229.

${ }^{86}$ Kelly 1974, 38-44.

${ }^{87}$ Andrieu (ed.) 1931-61, vol. 2, 422-423 (OR XI:19-22); Mohlberg (ed.) 1981, 45 (Lib. I, formula XXXIII, nos. 295 296). The translation is from Whitaker and Johnson 2003, 218. The Biblical reference is to Matthew 14:29-31. For discussion, Kelly 1985, 209.

${ }^{88}$ Labriolle 1926; Waszink 1947.

${ }^{89}$ Pace for instance Rahner 1931.

${ }^{90}$ Water: Andrieu (ed.) 1931-61, vol. 2, 445 (OR XI:92-93); Mohlberg (ed.) 1981, 72-73 (Lib. I, formula XLIIII, nos. 445-446). Salt: Andrieu (ed.) 1931-61, vol. 2, 419 (OR XI:5); Mohlberg (ed.) 1981, 43 (Lib. I, formula XXXI, no. 288).
} 
water, ${ }^{91}$ making an exorcism appropriate. The prayer over the salt has been referred to as a blessing, ${ }^{92}$ but even this entailed the priest's driving out some otherworldly beings. The prayers suggested that the Devil was connected with the carnal world, whereas the servants of God were meant to direct their minds to heavenly things. ${ }^{93}$ Certain gestures executed in the course of the ceremony likely reinforced the words in guarding against demonic influences. The rite incorporated the apotropaic application of the sign of the cross on the infants, done by the clergy and godparents. This was a gesture repeated several times, presumably to magnify its power. In the first scrutiny alone, the baby was crossed ten times by various clergy and the godparents. ${ }^{94}$

Ultimately, the goal of baptism was not primarily to assist in the earthly career of the recipient. It was designed to achieve salvation. In the Hanc igitur prayer of the first scrutiny, the priest offered the gifts for "servants... whom you have deigned to choose and call to eternal life..." ${ }^{95}$ The rites the children received were referred to as sacraments of eternity ( sacramentis aeternitatis), since they led to eternal salvation. ${ }^{96}$ God was asked to guide his family to salvation. ${ }^{97}$ God's people were supposed to delight in their salvation. ${ }^{98}$ Further, God worked toward human salvation, especially in providing help for those chosen to be baptized. ${ }^{99}$ The salt and chrism given to the children was said to be received in vitam eternam ("unto eternal life"), showing they had a positive effect on salvation; ${ }^{100}$ a similar phrase was used for the mixing of the bread and wine of the Eucharist. ${ }^{101}$ One formula further included eschatological references, for instance: "Jesus, who shall come to judge the living and dead by fire". ${ }^{102}$ It made no difference that the infants were not the ones actively assenting to their faith. As John the Deacon claimed in justifying infant baptism, salvation comes through someone else's profession, just as damnation came through another person's error. ${ }^{103}$

In the texts, one finds little reflection on the consequences of failing to receive baptism, which is logical since the assumption is that those who are submitting their children to it were already convinced of its value. One must turn to theologians to get an answer to this question. Most relevant from a papal perspective were the writings of Innocent I (401-17) and Gelasius I (492-96). ${ }^{104}$ Both popes drew on John 6:52-54 to show that without the Eucharist, one could not be saved, and because baptism was the entryway to reception of the Eucharist, in effect

For discussion, Kelly 1985, 211-213. The oil used in the confirmation after baptism was also subject to an exorcism, but this is not mentioned in OR XI. Cf. Mohlberg (ed.) 1981, 61-62 (Lib. I, formula XL, no. 384).

${ }^{91}$ Dölger 1909, 161-167.

${ }^{92}$ Kelly 1985, 205-207.

${ }^{93}$ Mohlberg (ed.) 1981, 42-43 (Lib. I, formula XXX, nos. 285, 287).

${ }^{94}$ Andrieu (ed.) 1931-61, vol. 2, 418, 420-424 (OR XI:3-4; 12; 13, 15; 17; 18, 19; 20; 21-22; 23; 24-25; 27).

${ }^{95}$ Mohlberg (ed.) 1981, 32-33 (Lib. I, formula XXVI, no. 196).

${ }^{96}$ Mohlberg (ed.) 1981, 33 (Lib. I, formula XXVI, no. 198).

${ }^{97}$ Mohlberg (ed.) 1981, 36 (Lib. I, formula XXVII, no. 227).

${ }^{98}$ Mohlberg (ed.) 1981, 39 (Lib. I, formula XXVIII, no. 256).

${ }^{99}$ Mohlberg (ed.) 1981, 39 (Lib. I, formula XXVIII, no. 257).

${ }^{100}$ Salt: Andrieu (ed.) 1931-61, vol. 2, 419 (OR XI:6); Mohlberg (ed.) 1981, 43 (Lib. I, formula XXXI, no. 289). Chrism: Andrieu (ed.) 1931-61, vol. 2, 446 (OR XI:97); Mohlberg (ed.) 1981, 74 (Lib. I, formula XLIIII, nos. 450-451).

${ }^{101}$ Andrieu (ed.) 1931-61, vol. 2, 101-102 (OR I:107: the Fiat commixtio prayer).

${ }^{102}$ Mohlberg (ed.) 1981, 67-68 (Lib. I, formula XLII, no. 419). The translation is from Whitaker and Johnson $2003,229$.

${ }^{103}$ Wilmart (ed.) 1933, 175.

${ }^{104}$ Innocent I: Goldbacher 1904, 720-721; Gelasius I: PL 59:36D-38B. 
baptism was required for salvation. Isidore of Seville interpreted the words of John 3:5 to mean that without the Eucharist salvation was impossible. ${ }^{105} \mathrm{He}$ asserted that one would be separated from the kingdom of Heaven if Original Sin were not washed away by baptism.

The last feature of this service related to the individual was that the baby held value in this society. The Gospel read at the scrutiny reveals one of the advantages of baptism: "I confess to you, O Father, Lord of heaven and earth, because you have hidden these things from the wise and prudent, and have revealed them to the little ones". ${ }^{106}$ The implication was that there is a positive valuation of the infant in its current state and that, in fact, being childlike was a good thing. One might argue that this is an obvious passage to bring up in this ritual context, but it clearly contradicts the older scholarly attitude that childhood was either to be ignored or denigrated. ${ }^{107}$ It fits well with recent scholarship that reads medieval childhood more sympathetically. ${ }^{108}$ Naturally, to bring children to be baptized in the first place represented concern for the well-being of the infant.

\section{Baptism and the broader society in Rome: collective level}

The effects of baptism radiated beyond the individual to the societal, collective sphere. This occurred on several levels at once. Roman orations, especially those as frequent, verbose, and elaborate as those in baptism, reveal the common attitude that prayer had the power to create new realities. ${ }^{109}$ Combined with the actions of the service, they made new Christians and set them on the path to salvation. The missionary Boniface (ca. 675-754) was concerned about the precise wording of the baptismal formula, exactly because of the power inherent in these words. ${ }^{110}$ What is interesting about OR XI is the rare glimpse we get in the scrutinies of the laity participating in prayer, with the expectation that it conferred a spiritual benefit - or else the clergy would not have requested it of them. The implication of repeatedly asking the group of laity to pray together in particular, was that corporate, collective prayer was more potent than that said by a solitary petitioner. ${ }^{111}$

OR XI also provides an illustration of the relationship between the clergy and laity in Rome. In this case, it is limited to how we see the two interact in the course of a liturgy, but it does provide valuable clues for the less documented interactions outside of worship. The first impression one derives from them is the hoary model of a domineering clergy presiding over the cowering faithful. And indeed, there is evidence for this view in OR XI. The clergy continually commanded the laity and they are expected to obey - the laity was made to stand in silence, kneel, rise, come forward, gather, and pray. ${ }^{112}$ In the first scrutiny, for instance, the

\footnotetext{
105 Lawson (ed.) 1989, 104-105.

${ }^{106}$ Andrieu (ed.) 1931-61, vol. 2, 425 (OR XI:31). The Biblical reference is to Matthew 11:25-30, esp. v. 25. The translation is from Douay-Rheims, with slight modification.

${ }^{107}$ Ariès and Baldick 1962.

${ }^{108}$ E.g., Hanawalt 1986; Orme 2001; Shahar 1990.

${ }^{109}$ Romano 2014, 179-201.

${ }^{110}$ Tangl (ed.) 1916, 141 (letter 68).

${ }^{111}$ Andrieu (ed.) 1931-61, vol. 2, 420, 424, 444 (OR XI:11, 26, 87): "Complete orationem vestram in unum".

${ }^{112}$ Stand silently: Andrieu (ed.) 1931-61, vol. 2, 424, 427, 429, 430-431, 437, 440 (OR XI: 27, 41, 46, 51, 55, 68, 70); Kneel: Andrieu (ed.) 1931-61, vol. 2, 420-421, 424, 444 (OR XI: 11, 17, 26, 87); Rise: Andrieu (ed.) 1931-61, vol. 2, 420, 424 (OR XI:11, 26); Come forward: Andrieu (ed.) 1931-61, vol. 2, 420, 427 (OR XI:10, 40); Gather: Andrieu (ed.)
} 
laity is commanded by the deacon: "Pray, you elect. Bend your knees. And after they have prayed, he says: Rise up. Complete your prayer as one, and say: Amen". ${ }^{113}$ Furthermore, the clergy mediated the laity's introduction into Christian society, protected it against evils, and paved the path to salvation. I would guard against reading the interaction too literally, however, since it is exactly in the liturgy where we would expect the clergy to be firmly in charge. This did not translate into complete control of the minds or bodies of the secular Roman populace, something that was never achieved. Clerical leadership in matters liturgical did precondition their assumption of power in the political sphere, but the laity was never pushed out entirely. Along similar lines, the relationship between the clergy and laity in a liturgical setting cannot be invariably envisioned as one in which the laity did whatever was ordered by the clergy. The modifications in the baptismal ceremony demonstrate the clergy adapting to suit the changing needs of the laity. As opposed to the set stational pattern of churches for regular papal liturgies, the scrutinies had no standard set of churches associated with them. ${ }^{114}$ Unlike the normal papal liturgies, it is possible to read the freedom to choose a church as a pastoral decision. ${ }^{115}$ The clergy could adopt churches that were closer to earlymedieval population centers like the Roman Forum or the banks of the Tiber rather than the ancient but distant churches in less populated regions of the city. ${ }^{116}$ This would make it easier for people to attend these gatherings. No doubt it still represented considerable travel for the faithful to go all the way to the Lateran basilica for the papal Mass on the Easter Vigil, but this was not the only church performing a baptism that night. ${ }^{117}$ In one instance a sense of mutuality emerged between the clergy and laity. The parents of the infants to be baptized and their godparents presented offerings (oblationes) to the clergy, and in turn, the names of the godparents would be read in the Memento prayer and the infants were mentioned in the Hanc igitur prayer; both were in the canon of the Mass. ${ }^{118}$ While the financial outlay in this case derived from the laity, it was an honor and spiritually beneficial to have one's names read out publicly at a sacred moment.

In addition to establishing a mode of interaction between the clergy and laity, baptism also gave the clergy a chance to carry out one of its special roles - that of sustaining a culture of orthodox Christian belief. During the scrutinies and before the baptism itself, the clergy catechized the laity. In the seventh century, Latin was still a living language in the city of Rome, and the native faithful would have understood the readings, prayers, and music in this language. While these would have been familiar features in most Roman services, at the third scrutiny the clergy took special pains to explain some of the most important elements. In what is known as the traditio evangeliorum the clergy provided an exposition of the symbols

1931-61, vol. 2, 426-427 (OR XI: 39, 40); Pray: Andrieu (ed.) 1931-61, vol. 2, 420-421, 424, 444 (OR XI: 11, 17, 23, 26, 87).

${ }^{113}$ Andrieu (ed.) 1931-61, vol. 2, 420 (OR XI: 11). The translation is from Whitaker and Johnson 2003, 245 (with modification).

${ }^{114}$ The scrutinies were not a part of the stational system: Cf. Willis 1968, 25-29. The churches for the next scrutiny had to be announced to the faithful: Andrieu (ed.) 1931-61, vol. 2, 426-427, 442 (OR XI: 37, 39, 40, 78, 80).

${ }^{115}$ Cf. Chavasse 1982.

${ }^{116}$ Meneghini and Santangeli Valenzani 2004, 157-205.

${ }^{117}$ Andrieu (ed.) 1931-61, vol. 2, 412-413; Fisher 1965, 18. E.g., OR I:15-17, which indicates that Santa Maria Maggiore, San Pietro in Vaticano, and San Paolo fuori le mura were used for baptism (Andrieu (ed.) 1931-61, vol. 2, 71-72).

${ }^{118}$ Memento: Andrieu (ed.) 1931-61, vol. 2, 425 (OR XI: 34); Hanc igitur: Andrieu (ed.) 1931-61, vol. 2, 426 (OR XI: 35). 
of the four evangelists, giving readings from each Gospel that verbally illuminated why each symbol was chosen. ${ }^{119}$ Afterwards, in the traditio symboli, the clergy chanted the creed and then broke it down into its constitutive parts and taught what they meant and how they could be used to protect against the Devil. ${ }^{120}$ As the priest chanted the creed, he put his hands on the infant, not to bless the child, but to serve as a surrogate of the non-verbal infant. ${ }^{121}$ Since the creed was not a regular fixture of the Roman Mass in this period, it would have been a precious opportunity to hear the core beliefs of Christianity. ${ }^{122}$ In addition, in the traditio orationis dominicae, the Pater noster was chanted at this Mass; ${ }^{123}$ perhaps because of people's familiarity with it, the prayer was never chanted straight through in the scrutinies. Instead, the clergy read portions of it, each of which was then explicated for the laity. All of the material that explained the texts would have been unfamiliar even to those who regularly attended Mass, all the more so since, at least in the context of a papal Mass, it does not appear that a sermon was regularly preached. ${ }^{124}$ In addition to the forms of religious instruction in the baptismal preparation, the parents and godparents would have been exposed to the extensive readings done at the Easter Vigil. ${ }^{125}$

The designer of these liturgies did more than provide material straight from the Bible that might have been encountered in other contexts, whether in worship or veneration. In the third scrutiny, two separate Biblical readings were combined to create a new composite reading. ${ }^{126}$ This situation appears so unprecedented that one previous scholar referred to it as "une seconde épître fort étrange". ${ }^{127}$ From OR XI we would only know that the incipit of this reading was Col 3:9b and its explicit was Rom 10:17-18, but from the eight-century Gellone Sacramentary, which was influenced by Roman traditions, it appears that the full reading started at Col 3:9b-3:16a and it ended at Romans 10:8-17. ${ }^{28}$ This kind of mixture of different Biblical texts is also attested in the antiphoner. ${ }^{129}$ The seventh-century sermonary of San Pietro in Vaticano mixes three previously distinct sermons (two by Augustine and one by Peter Chrysologus) to create an entirely new one. ${ }^{130}$ These three examples show that the Roman clergy did not hesitate to mix-and-match sources when it served their purposes and that sacred texts were not considered inviolate, even though this has received little attention in previous scholarship.

\footnotetext{
${ }^{119}$ Andrieu (ed.) 1931-61, vol. 2, 428-433 (OR XI: 44-60); Mohlberg (ed.) 1981, 46-48 (Lib. I, formula XXXIIII, nos. 299-309).

${ }^{120}$ Andrieu (ed.) 1931-61, vol. 2, 433-437 (OR XI: 61-67); Mohlberg (ed.) 1981, 48-51 (Lib. I, formula XXXV, nos. 310-318).

${ }^{121}$ Kretschmar 1970, 255, n. 371.

122 Jungmann 1962, vol. 1, 601.

${ }^{123}$ Andrieu (ed.) 1931-61, vol. 2, 437-440 (OR XI: 68-69); Mohlberg (ed.) 1981, 51-53 (Lib. I, formula XXXVI, nos. 319-328).

${ }^{124}$ Romano 2014, 50-51.

${ }^{125}$ Mohlberg (ed.) 1981, 70-72 (Lib. I, formula XLIII, nos. 431-442).

${ }^{126}$ Andrieu (ed.) 1931-61, vol. 2, 427-428 (OR XI: 43).

${ }^{127}$ Dondeyne 1932, 776.

${ }^{128}$ Dumas (ed.) 1981, 320-321. For discussion of this source, Stenzel 1958, 234-236.

${ }^{129}$ Hodie scietis mixes Exodus 16:6-7 and Isaiah 35:4. Hesbert (ed.) 1935, 12-13; McKinnon 2000, 103.

${ }^{130}$ Audiat in praesenti dilectio: MS. Città del Vaticano, Biblioteca Apostolica Vaticana, Archivio Capitolare di San Pietro C105, fol. 37v; Löw 1942, 148 (no. 16).
} 
Whatever one may think about the quality of the catechesis, few have avoided the conclusion that this religious instruction was all for show. OR XI gives no indication that its audience could have understood any of it, ${ }^{131}$ presumably because its primary audience was the infants. Although the text may not state it, my suspicion is that the real audience was instead the parents and godparents who brought the children. The catechism would have served as a review for them, and they in turn would have the responsibility to confer the lessons to the children as they grew. If true, this would mean that the parents and godparents had a more substantial role to communicate the lessons of the faith than in the ancient Church, where it would have been expected that adult converts would learn the lessons of the faith themselves. For fear of damnation, infants had to be baptized, but the adults around them had to pass down what they had learned through the baptismal process and other liturgies. ${ }^{132}$

As the last example indicated, the baptismal ceremony seems to forge a deeper relationship between the godparents and the newly baptized. This new intimacy is hinted at by how the godparents are referred to in OR XI - as those who retrieve them from the font, ${ }^{133}$ reflecting the physical gesture of taking the wet, wrapped infants from the font after they had been baptized. ${ }^{134}$ This bond may have extended beyond catechesis, although the only nearcontemporary source that has any indication of such observes the system in its absence. In Gregory I's Dialogues, there is an anecdote about a godfather who had raped his goddaughter. ${ }^{135}$ The only reason the violation could occur was because she was sleeping over at his house, likely a special privilege accorded to her because they were supposed to have had a close relationship. For Gregory, it was a cautionary tale since the godparent's drunkenness had allowed the sinful deed to take place.

Baptism forged new relationships, but simultaneously it reinforced pre-existing mentalities in Roman society. This is certainly true of gender roles. The precedence of boys that we would expect is wordlessly bolstered by ritual action: Boys are always on the right, the more exalted side over the left; rites are always done first to boys and only then to girls. ${ }^{136} \mathrm{~A}$ further dimension of the gendered nature of the ceremony emerges in one of the exorcism prayers in the first scrutiny, which was said only to girls. ${ }^{137}$ This prayer referred to the Biblical figure Susanna, a paragon of virtue and chastity in particular, even in the face of overwhelming pressure. The unspoken message was that Roman girls were meant to emulate Susanna. No equivalent prayer referencing a male Biblical figure who avoided sexual sin was included, suggesting that keeping one's chastity was more critical for female than male Romans.

The final societal effect that I would like to emphasize relies on an association drawn from the Bible. In several instances in the baptismal ceremony, the Romans are depicted as the new Israelites; through them, the Romans wrote themselves into Biblical history. Two prayers in the first scrutiny refer to God by using the Biblical epithets that first appeared in the Book of

\footnotetext{
${ }^{131}$ Neunheuser 1983, 111-112.

${ }^{132}$ Chavasse 1952, 14-16, although characterized here as something negative.

${ }^{133}$ Andrieu (ed.) 1931-61, vol. 2, 418, 425 (OR XI:2, 32): “qui ipsos suscepturi sunt”. Andrieu (ed.) 1931-61, vol. 2, 425, 441 (OR XI:34, 74): "qui ipsos infantes suscepturi sunt".

${ }^{134}$ Lynch 1998, 83.

${ }^{135}$ Vogüé (ed.) and Antin 1978-80, vol. 3, 108-112. Discussion in Lynch 1998, 34-37.

${ }^{136}$ Boys on right and girls on left: Andrieu (ed.) 1931-61, vol. 2, 418, 443 (OR XI: 2, 83). Boys attended to before girls: Andrieu (ed.) 1931-61, vol. 2, 420-424, 434-435 (OR XI: 13-16, 18-20, 21-22; 24-25; 62-63; 64-66).

${ }^{137}$ Andrieu (ed.) 1931-61, vol. 2, 422 (OR XI: 19); Mohlberg (ed.) 1981, 45 (Lib. I, formula XXXIII, no. 295).
} 
Exodus: "God of Abraham, God of Isaac, God of Jacob". ${ }^{138}$ In the same prayers, God was asked to protect the infants as he did those in the Exodus and in the desert; and those in attendance would be reminded that God had admonished the Israelites. This is more apparent in one of the readings from the first scrutiny, Ezechiel 36:25-29, especially v. 28: "And you will dwell in the land which I gave to your fathers, and you will be my people, and I will be your God". ${ }^{139}$ This is more than a typological reading in which the events of the Old Testament are fulfilled in the New: the fulfillment of this verse was understood to be among the audience of contemporary Romans.

\section{Conclusion}

Further evidence could be teased out of OR XI, but the general trend is clear. OR XI reflects and shapes who the Romans were in the seventh century. While it only depicts a small slice of the broader life in the city of Rome, it provides vital clues as to how Romans conceived their world on the individual and societal levels. Baptism brought people into Christian society, washed away Original Sin, and allowed them to achieve salvation at their deaths. It mediated their relationships with positive and negative supernatural forces from God to the Devil, which surrounded them. It forged connections between people, especially between the clergy and laity, fostered belief, and strengthened attitudes on gender. What is more, it set the Romans on the same level as the Biblical Israelites, or at least aspired to identify themselves as such. The emphasis in this source, as in all ordines, is on its clerical authors and officiators, but the baptismal ceremony would have had little meaning had the faithful not submitted their children to the clergy. Taking part in this ritual would have provided the laity with a lens to understand reality and their place in it, even if it is impossible for us to gauge completely their reception of this message.

That OR XI represents a new chapter in baptism is undisputed, although mapping out the changes in detail cannot be done with any certainty. However invisible it is to modern historians, there must have been a lengthy discussion from the end of antiquity into the earlymedieval period regarding the shape of baptism, and in particular, how it could be adapted to serve an infant population. In OR XI we only have the end product of this process. In our sources, the transformation of baptism emerges fully formed for the city of Rome. Whatever gestation led to its birth, the model it created proved influential for the city of Rome and far beyond it, for its capacity to shape a liturgy and the people who participated in it. If the bloody interruption of baptism at Forlì sapped that city of its strength, the continued celebration of baptism in Rome helped to sustain and shape the Eternal City well beyond the churches where it was performed.

\section{John F. Romano}

Benedictine College, Atchison, Kansas

jromano@benedictine.edu

\footnotetext{
${ }^{138}$ Andrieu (ed.) 1931-61, vol. 2, 421-422 (OR XI:14, 19); Mohlberg (ed.) 1981, 44-45 (Lib. I, formula XXXIII, nos. 291, 295). For the appearance of this phrase in the Bible, Exodus 3:6, 15-16, 4:5; Matthew 22:32; Mark 12:26; Acts 3:13, $7: 32$.

${ }^{139}$ Andrieu (ed.) 1931-61, vol. 2, 424 (OR XI:28). The translation is from Douay-Rheims, with slight modification.
} 


\section{BIBLIOGRAPHY}

Adriaen M. (ed.) 1971: Sancti Gregorii Magni Homiliae in Hiezechihelem prophetam (CCSL 142), Turnholti.

Andrieu M. (ed.) 1931-61: Les Ordines Romani du haut moyen âge, 5 vols. (Spicilegium sacrum Lovaniense, Etudes et documents 11, 23, 24, 28, 29), Louvain.

Ariès P. and Baldick R. (trans.) 1962: Centuries of Childhood: A Social History of Family Life, New York.

Battifol P. 1919: Leçons sur la messe (4th edn.), Paris.

Bethmann L. and Waitz G. (eds.) 1878: Pauli Historia Langobardorum (MGH, Scriptores Rerum Langobardicarum), Hannover.

Bishop E. 1918: Liturgica Historica: Papers on the Liturgy and Religious Life of the Western Church, Oxford.

Botte B. 1952: "L'interprétation des textes baptismaux", La Maison-Dieu 32, 18-39.

Bradshaw P.F. 2002: The Search for the Origins of Christian Worship: Sources and Methods for the Study of Early Liturgy (2nd edn.), Oxford; New York.

Buchinger H. 2016: "Gregorian Chant's Imagined Past, with Yet Another Look at the Roman Lenten Repertoire", in T. Berger and B. Spinks (eds.), Liturgy's Imagined Past/s: Methodologies and Materials in the Writing of Liturgical History Today, Collegeville, 143-175.

Bullough D.A. 1977: "Roman Books and Carolingian Renovatio", in Studies in Church History 14, 23-50; reprinted in Bullough D.A. 1991: Carolingian Renewal: Sources and Heritage, 1-38, New York and Manchester.

Chavasse A. 1952: “L'initiation à Rome dans l'antiquité et le haut moyen âge", in Communion solennelle et profession de foi, 13-32.

Chavasse A. 1958: Le sacramentaire gélasien (Vaticanus Reginensis 316): sacramentaire presbytéral en usage dans les titres romains au VIIe siècle, Tournai.

Chavasse A. 1960: "La discipline romaine des sept scrutins baptismaux", RecSR 48, 227-240.

Chavasse A. 1982: 'L'organisation stationale du Carême romain, avant le VIIIe siècle: Une organisation "pastorale"', Revue des sciences religieuses, 17-32.
Cramer P. 1993: Baptism and Change in the Early Middle Ages, c. 200-c. 1150, Cambridge and New York.

De Boor C. (ed.) 1883-85: Theophanis Chronographia, 2 vols., Lipsiae.

Deshusses J. (ed.) 1971-82: Le sacramentaire grégorien, ses principales formes d'après les plus anciens manuscrits, 3 vols., Fribourg.

Didier J.C. 1956: "Saint Augustin et le baptême des enfants", REAug 2, 109-129.

Dölger F.J. 1909: Der Exorzismus im altchristlichen Taufritual, Paderborn.

Dondeyne A. 1932: "La discipline des scrutins", $R H E$ 2, 5-33, 751-787.

Dudden F.H. 1905: Gregory the Great: His Place in History and Thought, 2 vols., London and New York.

Dumas A. (ed.) 1981: Liber sacramentorum Gellonensis (CCSL 159-159A), Turnholti.

Dutton P.E. 2004: Charlemagne's Mustache: and other Cultural Clusters of a Dark Age, New York.

Eliade M. and Trask W.R. (trans.) 1965: Rites and Symbols of Initiation: The Mysteries of Birth and Rebirth, New York.

Fisher J.D.C. 1965: Christian Initiation: Baptism in the Medieval West: A Study in the Disintegration of the Primitive Rite of Initiation, London.

Goffart W.A. 1988: The Narrators of Barbarian History (A.D. 550-800): Jordanes, Gregory of Tours, Bede, and Paul the Deacon, Princeton.

Goldbacher A. (ed.) 1904: S. Aureli Augustini Hipponiensis episcopi Epistulae (CSEL 44), Vindobonae.

Hanawalt B. 1986: The Ties that Bound: Peasant Families in Medieval England, New York.

Hanssens J.M. (ed.) 1948: Epistula Amalarii ad Carolum imperatorem de scrutinio et baptismo, in Amalarii episcopi opera liturgica omnia (Studi e testi 138), vol. 1, 236-251, Città del Vaticano.

Hardison O.B. 1965: Christian Rite and Christian Drama in the Middle Ages: Essays in the Origin and Early History of Modern Drama, Baltimore.

Hen Y. 1995: Culture and Religion in Merovingian Gaul, A.D. 481-751, Leiden; New York.

Hesbert R.J. (ed.) 1935: Antiphonale missarum sextuplex, Bruxelles.

Johnson M.E. 2007: The Rites of Christian Initiation: Their Evolution and Interpretation (2nd edn.), Collegeville. 
Jungmann J. A. 1962: Missarum sollemnia: Eine genetische Erklärung der römischen Messe (5th edn., 2 vols.), Wien.

Keefe S.A. 2002: Water and the Word: Baptism and the Education of the Clergy in the Carolingian Empire, 2 vols., Notre Dame.

Kelly J.N.D. 1972: Early Christian Creeds (3rd edn.), London.

Kelly H.A. 1974: The Devil, Demonology, and Witchcraft: The Development of Christian Beliefs in Evil Spirits, Garden City.

Kelly H.A. 1985: The Devil at Baptism: Ritual, Theology, and Drama, Ithaca.

Kretschmar G. 1970: Die Geschichte des Taufgottesdienstes in der alten Kirche, in K. F. Müller and W. Blankenburg (eds.), Leiturgia: Handbuch des evangelischen Gottesdienstes 5: Der Taufgottesdienst, 1-348.

Krusch B. (ed.) 1888: Fredegarii et aliorum chronica: Vitae Sanctorum ( $M G H$, Scriptores rerum Merovingicarum 2), Hannover.

Labriolle P. de 1926: "Pompa diaboli", in ALMA 2, 170-181.

Lawson C.M. (ed.) 1989: Sancti Isidori Episcopi Hispalensis De Ecclesiasticis Officiis (CCSL 113), Turnholti.

Lindsay W.M. (ed.) 1911: Isidori Hispalensis episcopi Etymologiarum sive originum libri $X X, 2$ vols., Oxford.

Löfstedt E. 1959: Late Latin, Oslo; Cambridge.

Löw G. (ed.) 1942: "Il più antico sermonario di San Pietro in Vaticano", RACr 19, 143-184.

Lukken G. 1973: Original Sin in the Roman Liturgy: Research into the Theology of Original Sin in the Roman Sacramentaria and the Early Baptismal Liturgy, Leiden.

Lynch J.H. 1986: Godparents and Kinship in Early Medieval Europe, Princeton.

Lynch J.H. 1998: Christianizing Kingship: Ritual Sponsorship in Anglo-Saxon England, Ithaca.

Maertens T. 1962: Histoire et pastorale du rituel du catéchuménat du baptême, Bruges.

Maldonado L. and Power D. 1979: Structures of Initiation in Crisis, New York.

Mango C. and Scott R. (trans.) 1997: The Chronicle of Theophanes Confessor: Byzantine and Near Eastern History, AD 284-813, Oxford; New York.

Mansi J.D. (ed.) 1759-1798: Sacrorum Conciliorum Nova, et Amplissima Collectio, 31 vols., Florentiae.

Martimort A.G. 1991: Les “Ordines, "les ordinaires et les cérémoniaux (Typologie des sources du Moyen Age occidental 56), Turnhout.
McKinnon J.W. 2000: The Advent Project: The LaterSeventh-Century Creation of the Roman Mass Proper, Berkeley.

Meneghini R. and Santangeli Valenzani R. 2004: Roma nell'Altomedioevo: topografia e urbanistica della città dal V al X secolo, Roma.

Mohlberg L.C. (ed.) 1981: Liber sacramentorum Romanae Aeclesiae ordinis anni circuli (Cod. Vat. Reg. Lat. 316/Paris Bibl. Nat. 7193, 41/56) (Sacramentarium Gelasianum) (Rerum ecclesiasticarum documenta, Series maior, Fontes 4) (3rd edn.), Roma.

Mohrmann C. 1958: "Sur l'histoire de praefari - praefatio", in C. Mohrmann, Etudes sur le latin des chrétiens, vol. 3, 291-305, Roma.

Mommsen T. (ed.) 1898: Libri Pontificalis pars prior: Gestorum pontificum Romanorum volumen I (MGH), Berlin.

Moreton B. 1976: The Eighth-Century Gelasian Sacramentary: A Study in Tradition, Oxford.

Nelson J. 1975: "Ritual and Reality in Early Medieval Ordines”, in D. Baker (ed.), The Materials, Sources, and Methods of Ecclesiastical History, 41-51; reprinted in Nelson J. 1986: Politics and Ritual in Early Medieval Europe, 329-340.

Neunheuser B. 1972: "Die Liturgie der Kindertaufe: Ihre Problematik in der Geschichte", in H. auf der Maur and B. Kleinheyer (eds.), Zeichen des Glaubens, 319-334.

Neunheuser B. 1983: Taufe und Firmung (2nd edn.) (Handbuch der Dogmengeschichte 4), Freiburg; Basel and Wien.

Nocent A. 2000: "Christian Initiation in the Roman Church from the Fifth Century until Vatican II", in A. Chupungco (ed.), Handbook for Liturgical Studies 4: Sacraments and Sacramentals, 49-92.

Norberg D. (ed.) 1982: S. Gregorii Magni Registrum epistularum (CCSL 140-140A), 2 vols., Turnholti.

Orme N. 2001: Medieval Children, New Haven.

Palazzo E. 1990: "Le rôle des libelli dans la pratique liturgique du haut Moyen Age: Histoire et typologie", Revue Mabillon 629-636.

Palazzo E. and Beaumont M. (trans.) 1998: A History of Liturgical Books from the Beginning to the Thirteenth Century, Collegeville.

Pfaff R. W. 1992: "Prescription and Reality in the Rubrics of the Sarum Rite Service Books", in L. Smith and B. Ward (eds.), Intellectual Life in the Middle Ages: Essays Presented to Margaret Gibson, 197-205.

Rahner H. 1931: “'Pompa diaboli”: Ein Beitrag zur Bedeutungsgeschichte des Wortes pompē - pompa in urchristlichen Taufliturgie", Zeitschrift für katholische Theologie 55 (1931): 239-273. 
Richards J. 1979: The Popes and the Papacy in the Early Middle Ages, 476-752, London and Boston.

Romano J.F. 2014: Liturgy and Society in Early Medieval Rome, Farnham and Burlington.

Sansterre J.M. 1993: Les moines grecs et orientaux à Rome aux époques byzantine et carolingienne, 2 vols., Bruxelles.

Shahar S. 1990: Childhood in the Middle Ages, London and New York.

Stenzel A. 1958: Die Taufe: eine genetische Erklärung der Taufliturgie, Innsbruck.

Tangl M. (ed.) 1916: Die Briefe des heiligen Bonifatius und Lullus (MGH, Ep. Selectae 1), Berlin.

Urdeix J. (ed.) and Lligadas J. (trans.) 1995: El bautismo en la Roma medieval: Ordo Romanus XI (Cuadernos Phase 65), Barcelona.

Van Molle M.M. 1964: "Les fonctions du parrainage des enfants en Occident: Leur apogée et leur degradation (du VIe au Xe siècle)", Paroisse et Liturgie 46, 121-146.

Van Slyke 2004: "Augustine and Catechumenal exsufflatio: An Integral Element of Christian Initiation", Ephemerides Liturgicae 118, 175-208.
Vogel C. Storey W.G. and Rasmussen N.K. (trans. and rev.) 1986: Medieval Liturgy: An Introduction to the Sources, Washington, D.C.

Vogel C. and Elze R. (eds.) 1963-72: Le Pontifical romano-germanique du dixième siècle, 3 vols., Città del Vaticano.

Vogüé A. de. (ed.) and Antin P. (trans.) 1978-1980: Dialogues, Grégoire le Grand (SC 251, 260, 265), 3 vols., Paris.

Waszink J.H. 1947: "Pompa diaboli”, VigChr 1, 13-41.

Whitaker E.C. and Johnson M.E. 2003: Documents of the Baptismal Liturgy (3rd edn.), Collegeville.

Willis G.G. 1968: Further Essays in Early Roman Liturgy, London.

Wilmart A. (ed.) 1933: "Un florilège carolingien sur le symbolisme des cérémonies du baptême, avec un Appendice sur le lettre de Jean Diacre", in Analecta reginensia: extraits des manuscrits latins de la reine Christine conservé au Vatican (Studi e testi 59), Città del Vaticano.

Wright D.F. 2007: Infant Baptism in Historical Perspective: Collected Studies, Milton Keynes; Waynesboro. 